\title{
DIE GESIGTE VAN DIE NEO-MARXISME
}

'n Ondersoek na die wese en identiteit van die Neo-Marxisme soos dit gestalte kry in verskeie na-Marxse ontwikkelingslyne

Ds. M. C. Boshoff (Salisbury)

\section{A. WAT IS NEO-MARXISME ?}

1. Probleemstelling

Ons weet nie sondermeer wat die voorsetsel „NEO" beteken nie. Het Marx in ons tyd herleef of 'n ombuiging, hersiening, aanvulling of selfs 'n korrektief op die oorspronklike visie van Marx gekom? Wat hou die naam, doelstellings en gees van Karl Marx lewendig en dreig om die Westerse lewenswyse en die Christelike godsdiens te vernietig met 'n leefwyse wat die Christelike geloof op sy kardinale punte aanval? Hoe verskil die Kommunisme, Marxisme en NeoMarxisme van mekaar? Is alle na-Marxse strominge Neo-Marxisties?

Ons kan ten minste vier na-Marxse of Neo-Marxistiese hooflyne onderskei: 1. die Sowjet en Sjinese Kommunisme; 2. die Ortodokse Marxisme oftewel Trotskyisme; 3. die Filosofiese Neo-Marxisme van Marcuse en ander; 4. en ook daardie Neo-Marxisme wat met die teologie 'n "huwelik" aangegaan het.

Vir 'n verstaan van die na-Marxse ontwikkelinge (i.c. NeoMarxisme) is eerstens ' $n$ basiese kennis van Marx self onontbeerlik. Daarna kan ons aantoon hoedat die lyne van 1840 - 1978 uitmekaar geloop het.

2. Die suiwer Marxisme van Karl Marx self. (1818-1883)

$0 m$ ' $n$ enkelvoudige en volledige interpretasie van Marx aan te bied is bykans onmoontlik omdat Marx-literatuur steeds aangroei. Nuwe ondersoekers „ontdek" steeds nuwe gesigspunte by Marx. 'n Mens moet ' $n$ beeld van Marx uit sy interpreteerders probeer saamvat.

\subsection{Die sogenaamde veronderstelde "jonge Marx"}

Die jong Marx sou geskryf het oor menslike natuur en sosiale verhoudinge. Sy vroeë geskrifte is basies humanisties en sê dat die mens nie leef soos wat hy moet nie en die samelewing laat dit ook nie toe nie. "The work of the early Marx is structually akin to that of the Christian doctrine of man. It involves value judgements on the nature of man and implies a certain faith and hope for man. It is to these elements that the Neo-Marxists have turned in a fresh way."

\subsection{Die eintlike of volwasse Marx}

Wanneer Marx later sy ,vervreemdings" problematiek wou oplos doen hy dit in ekonomiese terme. Sy uitgangspunt is sy materialistiese geskiedenisbeskouing. Die samelewing, bestaande uit 'n onderbou (substruktuur nl. die ekonomiese lewe) en 'n bobou (die res van die samelewingsorde), word beheers deur die dinamiese ont- 
wikkeling van die onderbou. M.a.w. die ekonomie bepaal die samelewing uiteindelik in al sy fasette. Om 'n einde te bring aan alle ellende moet die onderbou radikaal hervorm word. Dit gebeur wanneer gemeenskaplike besit en beheer die heersende ekonomiese sisteem (vanself) deur 'n stelsel van ekonomiese gemeenskaplikheid vervang.

Die eintlike sondebok van kapitalisme, bereik teen die middel van die $19 \mathrm{e}$ eeu sy hoogptepunt in die industriële kapitalisme van Europa. Hierdie stelsel bring die klassestryd tussen die bourgeoisie (,haves") en proletariaat ("have-nots") na vore. Hierdie stryd in die onderbou word voortgesit in alle vlakke van die bobou. Godsdiens byvoorbeeld, is 'n skepping van die bourgeoisie wat dien as opium van die proletariaat.

Die gedetermineerde dekadensie van die kapitalisme word uitgespel in sy eie ontwikkelingswette (of sub-strukturele dinamika): akkumulasie van kapitaal; konsentrasie daarvan in die hande van 'n al-hoe-kleiner wordende monopolie; toenemende ellende onder proletariaat en uiteindelik permanente krisis. Intussen groei die klassebewustheid onder die proletariaat en uiteindelik volg die revolusie as bevryding van die proletariaat. Die selfwerksaamheid van dié histories-gedetermineerde proses word verder aangehelp deur die proletariaat. Proletariaat dien net as katalisator vir die revolusie. Die eerste fase ná die revolusie word gekenmerk deur 'n proletariërdiktatuur. Die ekonomiese maatstaf is: arbeid volgens vermoë en vergoeding volgens prestasie. (Lenin noem dié fase Sosialisme). Hierdie fase het Marx gedetailleerd uitgewerk in Das Kapital.

2.3 Die "Ou Marx" moet nou die finale of na-revolusionêre fase breër uitwerk. Tog is Marx opvallend vaag hieroor. Hierdie vaag. heid het tot menige latere uiteenlopende Marx-interpretasies gelei. Die fase moes die Kommunisme beskryf waarin alle kapitaal in openbare besit is, waarin sosiale gelykwaardigheid heers, waarin geen klasse, godsdiens, uitbuiting, nasionalisme en state sou wees nie. Ware vrede moes internasional gevestig wees. Selfverlossing deur die universele proletariaat maak die hele wêreld vry. Marx het 'n universele era ingelei en impakt gehad omdat hy op 'n faset van menslike ellende gewys het.

Marx se „profesie" het egter nie uitgekom nie. Die historiese determinisme blyk onwaar te wees. Die kapitalisme floreer deur 'n vakbondgesindheid wat die klassestryd in die kiem gesmoor het. Latere Marxiste het steeds die probleem gehad om die revolusie aan die gang te kry. Die gevolg is dat hierdie oorspronklike Marxisme toepaslik gemaak moes word. Marx het vanuit sy Sitz im Leben, die voor- en na-oorlogse omwentelings op politieke, ekonomiese, godsdienstige, filosofiese gebied, daadwerklik probeer aantoon dat die mens homself kan verlos uit sy ondermaanse ellende.

\section{Die eerste twee hooflyne in die na-Marxse ontwikkelings}

Aanvanklik lyk dit asof Marx uit Wes-Europa verdwyn en net in Rusland, Sjina en ander ,kommunistiese" lande gevestig raak. Die (groter) omvang van die Neo-Marxisme bewys die teendeel. 
3. Die term „Kommunisme” gebruik ons as versamelnaam vir alles agier die ystergordyn. Lenin (1870-1924) manipuleer die klassieke Marxisme tot Bolsjevisme. Marx se universalisme swaai hy om tot Kollektiwisme wat uiteindelik die hele opset bepaal het van dic Bolsjevisme as diktatuur van die party oor die proletariaat. Marx se dinamiese determinisme stel hy ter syde deur die revolusie te probeer versnel d.m.v. militêre en politieke optrede. In plaas daarvan dat die proletariaat die revolusionêre agent moet wees (Marx), laat hy die kommunistiese party as frontgroep namens die nog voornemende proletariaat optree. N.a.v. Rosa Luxenburg bou hy ook nog Marx se kapitalisme-teorie uit: $\mathrm{Na} 1870$ sou die stadium van beleggingskapitalisme posgevat het wat lei tot anneksasie oftewel imperialisme oor ander lande. Dit lei tot oorlog tussen imperialistiese moondhede en uiteindelik die krisis as bedding vir kommunistiese revolusie.

Stalin $(1879$ - 1953) vereng genoemde party-diktatuur nog verder: diktatuur deur een man nl. hyself! Hierdie Stalinistiese totalitarisme beweeg op een lyn ver van Marx af. Stalin skep selfs die NasionaalSosialisme (in kontradiksie met Marx). Stalin wou, omdat die 1917 Bolsjevistiese revolusie nie suksesvol opgevolg is in die res van Europa nie die sosialisme eers binne die grense van Rusland vestig. Daarom is die kommuniste in die res van die wêreld sedert 1925 geroep om allereers die Russiese Kommunisme te beveilig. Alle kapitalistiese oftewel nie-kommunistiese lande word nou sondermeer as vyande bestempel. Dié nasionaal-sosialisme leef voort by sy epigone. Waar Stalin nog bereid was om met die grootste vyand 'n verbond te smee (indien dit sou help om die vyand te oorwin), het Chroesjtsjof gemeen om kommunisme beter deur geweldlose taktiek (diplomasie, geestelike aftakeling en indoktrinasie, geldelike voorskotte wat die begunstigde aan die donateur bind) te propageer. Mao Tse Tsung het as voorstander van oorlog en geweld verkondig dat alle politieke mag voortspruit uit die loop van 'n geweer. Hy wou nie met die kapitaliste oor vrede onderhandel nie, want dit sou vertroue inboesem en verraad teenoor kommunisme wees.

A. Kee sê: „Communism is what happens in the U.S.S.R.”. Onder Marxiste is daar egter groot stryd. Baie sê dat die U.S.S.R. Stalinisties is glad nie Marxisties nie. "With the collapse of the monolithic front of the Cold War period there has been a proliferation of parties. Each of these splinter groups claims to represent the true Marixst position and there is considerable bitterness among them." Verder: "the communism of the Soviet Union is now rejected as actually contrary to Marx. I suppose that Stalin is the antiMarx"(!) (Kee, A. 1972, p. 20. My kursivering).

3.2 Die Ortodokse Marxisme (Internasionaal-Sosialisme, Trotskyisme).

'n Kenner , an die na-Marxse ontwikkelinge, K. J. Kraan, is van mening dat die term "Neo-Marxisme" slaan op die radikale vleuel van die sosiaal-demokrate wat omstreeks 1900 as party in Duitsland uitgekristalliseer het. (Kraan K. J. 1957 p. 59-62). Hiervan was Rosa Luxenburg die geniale koersaanduider. Op haar voetspoor is 
die „ortodokse Marxisme” (wat Kraan „Neo-Marxisme” noem) uitgebou. Trotsky $(1879-1940)$ het Stalin heftig teengegaan omdat lg. die oorspronklike (ortodokse) Marxisme sou verkrag het. Later volg Isaack Deutscher wat, steeds op een lyn Marx se kapitalistiese teorie uitbou: Die Weste verkeer in 'n post-kapitalistiese fase waarin almal (werkgewer en werknemer die proletariaat vorm) vir enkele base werk. Hierdie base, of élite-groep, moet nog verdwyn wanneer genoemde proletariaat begin saamstaan. Vir beide Trotsky en Deutscher bly die proletariaat dus die revolusie-agent. "The revolution will either be the work of the workers, or it will not be at all" (vgl. Deutscher I. 1972, p. 31 -61). Hy wys Marcuse se „nuwe proletariaat" af (p. $252-4)$.

Nog steeds in lyn mel Marx se vae utopisme, wys Deutscher konsekwent elke metafisiese beskouing oor die menslike natuur af. Die uitgangspunt bly dat die sosiale toestand die mens se natuur bepaal (vgl. Deutscher, I. 1972, en Socialist man p. 232 - 3). Daarom stel hy ook dat Marxiste nie in die eerste plek dink in terme van ewigheid en hiernamaals nie. „We are concerned with man's condition in society-which is his own creation and which he is capable of changing" (Deutscher, I. 1972, p. 232). Dit was ook Marx se standpunt. Deutscher beskuldig vir Marcuse van seniliteit(!). 'n Mens kan nie die volwasse Marx oorboord gooi en teruggryp na die onvolwasse Marx nie. Dit is agteruitgang, nie vooruitgang nie, sê Deutscher.

\subsection{Samevatting tot so ver}

Die eerste twee hoofstrominge in die Na-Marxse ontwikkelinge toon dus vele verwantskappe en tog ook radikale verskille. Deutscher noem homself Marxis, maar kritiseer Sowjet Kommunisme. Luxenburg, Lenin en Deutscher is as Marxiste konserwatief, eng, behoudend op hul voorganger Marx. Hulle laat nie toe dat daar nuwe dimensies bygewerk word nie. Teenoor die geslotenheid van die Marxiste word die Neo-Marxiste gekenmerk deur liberale openheid.

Dic een saak wat grondliggend is aan alle Marxisme-variante is die horisontalistiese geloof in die maakbaarheid van 'n toekoms d.m.v. die afbraak van die bestaande en die selfopbou van 'n menswaardige utopie. En hiérdie humanistiese geloof het aan die naam van Marx die vitalisme verleen om dit oor eeue heen steeds meer en meer lewensvatbaar te maak. Vandag staan die naam van Marx geskrywe oor die kontemporêre kultuur, politiek en teologie. Wat die eerste twec strominge in die na-Marxse ontwikkeling betref (hierna genoem "Marxisme" t.w. die Nasionaal-sosialisme en die Ortodokse Marxisms), het hulle hierdic geloof gebaseer op die materialistiese dialektiek van tese, antitese en sintese.

Ons kan dus (ten minste) vier korrelatiewe kenmerke noem:

1. Die Marxisme sluit aan by die volwasse Marx.

2. Hulle ontwikkel ' $n$ geslote sisteem (TOE) min of meer in lyn met Marx sodat ons hulle nie as "nuut" sal bestempel nie.

3. Hulle handhaaf 'n vae futurlogie net soos die „ou Marx".

4. Die deurlopende geloof in die menslik-maakbaarheid van 'n toekoms. 
4. Die derde hooflyn in die Na-Marxse ontwikkeling: DIE FILOSOFIESE NEO-MARXISME

4.1 K. J. Kraan dui vier skole in die na-Marxse ontwikkeling aan t.w. die reeds behandelde "Neo-Marxisme" wat ons "Marxisme" genoem het; die "ortodokse" Marxisme van Bebel, Liebknecht en Kautsky; die ,austromarxisme” (O. Bauer, K. Renner, M. Adler wat soos Lenin en Stalin die staat as revolusionêre agent neem) en die "revisionistiese" of "reformistiese" Marxisme waarvan veral Bernstein 'n voorstander was. (Kraan, K. J. 1957, p. $59-62$ ). Hierdie revisionistiese rigting wou Marx se historiese materialisme hersien. Kraan wys daarop dat dieselfde soort besware teen Marx se ekonomiese visie ten grondslag lê aan wysiginge wat nog later as Bernstein s'n tot stand gekom het deur Marx met Kant of met Freud te verbind (Marcuse). Daar het dus reeds tydens die Lenin-Stalin orde 'n mate van openheid ontstaan m.b.t. die Marx interpretasie.

4.2 Die Hoofsetel van die Filosofiese Neo-Marxisme: Die FrankfurterSchule.

\subsubsection{Horkheimer en Adorno se Dialektik der Aufklärung}

In 1947 verskyn Horkheimer en Adorno se boek „Dialektik der Aufklärung”. Eers in 1969 is die boek „herontdek" en herpubliseer. Die tema (titel) wil sê dat die oermens in vrees vir die kosmiese magte geleef het, maar dat die Aufklärung (Verligting) beloof het om hom d.m.v. die Rede daaruit te verlos. Die rede sou die natuur beheers. Weldra blyk egter dat die belofte nie gestand gedoen kon word nie. Dit is die dialektiek van die Verligting. Die mens is toe nié bevry nie maar vervreem. Verligting het ontaard in verblindende oorheersing deur die mens se eie geoutomatiseerde industrialisasie-sisteme (vgl. Marx). Die nood van die Rede is dat dit wel kan beveel en beheers, maar dat dit nie die mens uit hierdie dialektiek kan verlos nie. Die vraag is nou: hoe kan die maatskappy verander word om los te kom van sy eie dialektiek? Die antwoord wat Horkheimer en Adorno bied, is dat die Rede nie meer verder moet beheers nie (dit vererger net die dialektiek). Eerder moet daar 'n versoening kom tussen Rede en natuur d.m.v. 'n gewysigde gebruik van die outonomie van die Rede. Die Rede moet oorgaan tot kritiek: radikale selfkritiek en maatskappykritiek.

Die kritiese teorie is in beginsel nog eie aan Marx: kritiek kom op uit die praktyk en keer sig dan teen die in die praktyk-gegrocide misstande totdat dit in politieke dade omgemunt kan word.

Tog reik Horkheimer en Adorno se kritiek verder as dié van Marx: Dit is nie net gerig teen die substrukturele ekonomiese sisteem nie, maar teen die ganse sisteem wat die ganse mensdom (en nie net die proletariaat nie) onderdruk.

Die kritiek reik ook dieper as die van Marx. Horkheimer en Adorno stel Marx se determinisme ter syde en bekritiseer nou die mensheid self: die menslike heerssug en selfhandhawingsdrang. Kom dus los van Marx se „pessimisties-bepaalde geskiedenis-proses”.

Die nuwe kritiek van Horkheimer en Adorno is ook anders gerig as dié van Marx. Marx soek na die ryk van vrede/vryheid bo die 
natuur maar Horkheimer en Adorno sê die natuur self sug om bevryding. Daarom kry die kosmiese, horisontale verlossing soveel meer nadruk.

\subsubsection{Die IMPETUS van die Filosofiese Neo-Marxisme: Herbert Marcuse}

Marcuse (gebore 1898, 'n Duitse jood soos Marx, ontvlug die Hitler regime en word professor in Amerika), sluit aan by die Frankfurter Schule se dialektiek: Die rasionele natuurbeheersing slaag nie maar lei tot 'n totalitêre tegnologiese samelewingsorde wat (1) die hele mensdom onderdruk en (2) tot die één dimensie van die „establishment" verdinglik. Maatskappykritiek is die kritiese houding wat daarop afgestem is om hierdie dialektiek te ontmasker deur middel van 'n vernietigende revolusie. So sal die samelewing verander word tot 'n menswaardige een. Takties is dit nie meer die proletariaat wat die revolusie aan die gang moet kry nie (hulle word gekul), maar die nuwe proletariaat t.w. die jong intellektueles en dic negers.

Sy mikpunt is om nie net ' $n$ kwantitatiewe verskil te verkry nie (Marx: meer lewensmiddele; Stalin: meer magsmiddele), maar 'n kwalitatiewe verskil. Die wêreld moet nie verower word nie (Kommunisme) maar verbeter word (Neo-Marxisme). Dit gaan om 'n totale reorganisasie van die menslike lewe op die basis van Freud. Die nuwe aarde moet gebou word waarin die mens ' $n$ spelende wese (homo ludens) is. Erotiek en estetika is die nuwe moraal van die nuwe wêreld.

S. U. Zuidema, in sy „Revolutionaire maatschappijkritiek van Herbort Marcuse" (1970. p. 86-7), tipeer Marcuse se denke as „Mythologiserende religiositeit" wat teruggryp op die Griekse Orphiek. Hy noem dit ook "humanistische hedonisme" (p. 185) en „,neo-religieuse paganisme" (p. 204). Dit is ten beste 'n gewysigde Marxisme; 'n verstrengeling van neofreudianisme met Marxisme. Dit is noodwendig gewysig omdat dit op 'n post-Marxse situasie slaan (p. 91, 195, 199). Van Marx neem Marcuse oor (die hoop op) die realiseerbaarheid van 'n volledig menslike heilsryk. In ander opsigte, skryf Zuidema, is Marcuse se denke ,niet alleen geen Neo-Marxisme nie, maar een anti-Marxisme' '(p. 177). Zuidema bedoel bv. Marcuse se individualisme teenoor Marx se universalisme en ook bv. Marcuse se antropologie. By Marx het die arbeid vooropgestaan maar by Marcuse is juis van die teenoorgestelde, die hoogs individuele spelende eroties-estetiese mens sprake (p. 188ev. Vir Marcuse kyk Duvenage, S. C. W., 1972, p. $11-12)$.

4.2.3. Die IMPAK van die Filosofiese Neo-Marxisme: Die "New Left"

Die impak van persone soos Marcuse, Habermas en Adorno word gemeet aan die omvang van die „New Left" beweging. Dit is die versamelnaam vir studente aktivisme, geweld en anargisme. (Kyk verder van Wyk, J. H. Die opvoedingsleer van die "New Left". Diktaat 50/77, PU vir CHO).

Oor die tipering van die New Left skryf Duvenage, S. C. W. (Studenteopstandigheid, 1973, p. 17): „Die verklaring van die „Old 
Left" dat kapitalisme en imperialisme of kommunisme die grondoorsake van die kwaad is, was te simplisties en onbevredigend. Die "New Left" het daarom met 'n duideliker spesifisering van die kwaad gekom: Dit is geleë in alle soorte formele en vaste institute of instellings. Hul kritiek is nou dat die groot en magtige institute alle dele van die samelewing misbruik.

Volgens J. E. Hoover $(19-$ p. 426) is daar ideologiese nuanses binne die geledere van die New Left. Onder andere: „representatives of the nihilistic, anarchistic philosophy (who) would be satisfied simply with the destruction of our form of government to be followed by an ill-defined communal state" (m.a.w. geweld ter wille van geweld). Onder hierdie geledere is daar ook sekere sterk politiesingestelde groepe wat nader aan die Trotskyisme lê as aan Marcuse.

In 1968 is Marcuse doodgeskreeu toe hy voor studente in WesBerlyn opgetree het. Dieselfde geld vir prof. Zürgen (Vrye Univ. Berlyn) wat die aanstelling van 'n Trosky-professor gekritiseer het en toe deur studente byna vermoor is. (Vgl. Die Transvaler, Don. 6 Julie 1972). Ook S. C. W. Duvenage stel dit duidelik dat die studente-aktiviste Marcuse nie slaafs navolg t.o.v. ,al die konsekwensies van sy anargistiese idees nie". Hulle gaan selfs daarmee verder. (Duvenage, S. C. W., 1972, p. 12). Sedert 1970 egter het daar ' $n$ afname gekom in die drastiese politieke aktiwiteite van die New Left. (Duvenage, S. C. W., 1972, p. 7). Veral die „Kulturele revolusie" kry nou aandag. Tans, skryf Duvenage (Studenteopstandigheid, 1973, p. 27) word dit vergestalt in 'n uitdaging en verwerping van outoriteit op elke gebied. Dit kom tot uiting in 'n totaal nuwe benadering van moraliteit. Seksuele vryheid voor die huwelik, homoseksualiteit en aborsie word as deel van die nuwe moraliteit aanvaar. Marcuse is "hierdie Neo-Marxistiese denker" wie se teorie op „ekstreme individuele liberalisme uitloop". Hierdie dinge, veral die hele opset van gesagsafbraak is uitwasse van die humanisme (Duvenage, S. C. W. 1972).

Ons kan dus konkludeer dat die oopstel van Marxisme se „jeremiaanse tema" (vgl. Jer. 1:10) gekoppel aan die humanisme (van die "jonge Marx"?) en die utopisme (van die „ou Marx"?) al hoe meer vervloei het in 'n steeds breër wordende stroom waarin die gestalte van Karl Marx al hoe meer vervaag agter die newels van steeds nuwe invloede.

Die vraag is net: waar hou hierdie Neo-Marxisme op? Sou ons vandag bv. die boodskap van 'n poplied wat sing van dwelms en revolusie, vrye liefde en hoop as Neo-Marxisties kon tipeer? Op die oog af „nee”. (Daar sit tog asseblief nie 'n rooi kommunis met 'n masjiengeweer agter elke popliedjie nie!) Maar dieperliggend tog wel in 'n sekere sin ,ja". Dink ook aan die moderne kuns (die absurde is mooi, moderne kleredrag (unisex-gelykmaking); allerlei „,niksseggende" en tog revolusonêr of moraal-afbrekend prcgnante simbole en tekens: (omgekeerde kruis, gebyte appel, omgekeerde rangkentekens, „Jesus loves you").

Die Filosofiese Neo-Marxisme loop dus uit op 'n vloedgolf van Neohumanisme, Neo-liberalisme, Neo-utopisme. Die eksistensialisme, nihilisme en die hippiedom is ook hiermee verwant. 
4.3 'n Nuwe rigting: Die filosofies-sosiologiese Neo-Marxisme van P. Thoenes

Thoenes wil uitdruklik ortodoks-Marxistiese lyne trek. Tog meen ek, is hy een van die duidelik-herkenbare Neomarxiste en wel op grond van die volgende: In sy werk „De verloochening van het Marxisme" (1961, p. $20-44)$ wys hy op die vloeibare interpretasiemoontlikheid van Marx. Marx het nie één analise met één vasstaande utopistiese visie verkondig nie, maar vanuit sy tyd die aanvang van 'n voortrollende aldeur veranderende sosiale proses geskets. Ander tye en Marxisties-gewysigde toestande sou vanselfsprekend om nuwe taktiek vra. In hierdie sin, betoog Thoenes, bestaan Marxisme vandag nog ondanks die feit dat Marxisme en Sosialisme se weë aan die einde van 19e eeu uitmekaar geloop het. Soos LeninistiesStalinistiese kommunisme vandag Marxisme verwerp en verloën, so het die Sosiahsme destyds dieselfde Marxisme verwerp. Marxisme is nie tot Oos-Europa beperk en geen anachronisme in Wes-Europa nie (vgl. Deutscher, I., p. 176).

Thoenes sluit aan by Marx se „geloof/hoop" in die maakbaarheid van 'n ideale samelewingsvorm waarin die mens sy natuurlike bestemming sal en kan vind. Marx het gekonsentreer op die klassemaatskappy van sy tyd. Volgens Thoenes (p. 5, 7, 42. Vgl. ook Fischer, E. „Wat Marx werkelijk heeft gezegd", p. 78-81) het Marx ook bedoel dat elke daaropvolgende historiese tydperk die veranderingstaktieke van vorige tydperke moet hersien; óns situasie vra 'n nuwe interpretasie en -metodes; én die Marxisme kan dié wysigings akkommodeer. Daarom interpreteer Thoenes Marx en sy geskrifte anders en beklemtoon die humanisering van die mens asook 'n niestatiese, nog steeds ( $r$ )evolverende dialektiese proses.

Tweedens beveel Thoenes aan dat sosioloë wat deesdae die „jonge Marx" genoem word (p. 2 e.v.) en werke van sosioloë soos Geiger, Freyer, Mannheim en Dahrendorf moet begin lees in lyn met die humanisme van die jong Marx. Sosiologie aan die Marxisme gekoppel moet die samelewing verander d.m.v. wat genoem word demokratisering en maatskaplike herstrukturering langs ander as streng politieke weë.

\subsection{Samevatting van die Filosofiese Neo-Marxisme}

1. Grondliggende en deurlopend is steeds die geloof/hoop in die maakbaarheid van 'n toekoms d.m.v. afbraak van die status quo en selfopbou van die utopie (die „Jeremiaanse tema”). Takties is daar wisselende antwoorde: dit wissel tussen gradasies van blocdige tot bloedlose revolusie (maar steeds revolusic). Dit neem die Neo-Marxisme oor van die "Volwasse Marx". Die oogmerk is steeds kollektiewe ondermaanse verlossing d.m.v. horisontale vernuwing. Die samelewing moet verander word. Marcuse en die New Left gaan hier op die pad van ekstreme individualisme maar dit bly steeds horisontale selfverlossing deur die daad (vg. L. Floor, 1976, p. 17) m.a.w. basies humanisties en horisontaal.

2. Konsekwent vind die Neo-Marxiste aansluiting by die humanisme 
van die ,jonge Marx". Daarom kan die Neo-Marxisme getipeer word as neo-humanisties en neo-liberalisties.

3. Dit wat die Neo-Marxisme nou eintlik nuut mak is hul openheid. Die Marxisme is "toe", geslote, op een lyn met Marx. Die Neo-Marxisme is "oop". Hulle laat gans nuwe wêrelde toe by hul Marixtiese basis. Marcuse het Freud ingelaat; Thoenes betrek die Sosiologie. (Bloch e.a. bring die Teologie in!)

4. Met hul openheid kon hulle ook die „veronderstelde ou Marx" akkommodeer sodat daar vir hulle genoeg ruimte is om aan Marx se vaagheid betreffende die utopie, konkrete gestalte te gee. Daarom is die Neo-Marxisme ook oorwegend futuristies ingestem. By die Neo-Marxiste moet ons egter in gedagte hou dat hulle juis nie 'n nuwe establishment wil skep nie. (Dit is juis hul beswaar teen die geslote politieke sisteem van die Sowjet-kommunisme). Marxisme het 'n klaslose maatskappy in die oog. Neo-Marxisme het 'n helderder omlynde maatskappylose utopie in die oog waar die mens alles sal wees en in almal. (Vgl. Duvenage, S. C. W., 1972, p. 12 oor Marcuse se utopie: arbeid i.v.m. libidinale genot). Die heropbou van die utopie is dus ver by Marx se idees verby. (Vgl. Floor, L., 1976, p. 19).

5. Die vierde hooflyn in die na-Marxse ontwikkeling: DIE TEOLOGIESE NEO-MARXISME.

\subsection{Inleiding en Probleemstelling}

Die onbeantwoorde vrae m.b.t. die vrae en antwoorde van die „teologiese Neo-Marxisme" bemoeilik die ondersoek.

1. In hoeverre kan hierdie rigting as Neo-Marxisties bestempel word? Het die benaming "Teologiese Neo-Marxisme" werklik bestaansreg? In sekere gevalle is dit maklik: Bloch, Shaull, Verkuyl en andere maak vrylik gebruik van teologiese begrippe en dogmas om hul Neo-Marxistiese idees lewensvatbaarheid te gee. Andersins, wanneer ons die hele spektrum van die moderne - of ,nuwe teologie" in oog het moet mens noodwendig toelaat vir graadverskille: ekstreemrevolusionêre tot gematigd - of glad nie revolusionêr. K. S. van Wyk de Vries (1967, p. 32) vestig die aandag pertinent op die gevaar om kategories alles of af te maak as „kommunisties" of as „establishment". (Vgl. ook Heyns, J. A., 1957, p. 19. Heyns, J. A., 1969 , p. 97. Floor, L., 1976, p. 19).

2. 'n Tweede probleem wat hiermee verband hou, is die vraag na die wese van die "nuwere teologie". Lê hul identiteit nie juis (grootliks) daarin dat hulle die Marxisme geakkommodeer het tot 'n ,Teologiese Neo-Marxisme" nie? Of het die nuwere teologie onafhanklik van die Neomarxisme ontstaan en toe daarby aangesluit sodat ons eintlik moet praat van 'n "Neo-teologiese neo-marxisme". Of moet ons beide moontlikhede as die eintlike aanvaar? Floor vestig die aandag hierop: „Aan die een kant het die Neo-Marxisme reeds die nuwere teologie beinvloed maar andersyds vind ons ook 'n duidelike toenadering van die nuwere teologie tot die neomarxisme." (Floor, L., 1976, p. 23, 24). 
3. 'n Derde probleem is die verklaring van die genoemde sintese. „Hoe moet ons die verskynsel verklaar dat die nuwere teologie in die greep van die neo-marxisme kon kom? Was die stootkrag van die Neo-Marxisme so sterk of was die verweer van die nuwere teologie so swak? (Floor, L., 1976, p. 23). Floor verwys na sewe tipiese karaktertrekke van die nuwere teologie waarin „ons al sonder veel moeite die Neo-Marxisme herken" (p. 19-23) en dan ook nog na drie faktore wat die proses aangehelp het t.w. historisme, sekularisasie en evolusie (p. 23 - 24).

\section{Christendom en Neo-Marxisme as probleem}

A. Troost kritiseer die ,naieve paralleliseren van het Christendom en Neo-Marxisme" (Troost, A., 1969(b), p. 5. Vgl. Idem (a) p. 4) en stel dan: „De geschiedenis der sosialistische ideën is van meet of een soort spiegelbeeld geweest van de bijbelse boodschap inzake het koninkrijk Gods op de nieuwe aarde" p. 4). Die Christendom het, volgens Troost, in hierdie stroming 'n ,humane bondgenoot" begroet in die stryd teen die anti-humane ontbindingsverskynsels van die totalitaristiese humanisme. Daarby, beweer hy, het die Bybclse begrippe insake geregtigheid, vrede, naasteliefde, verdwyning van armoede, leed en onreg, nog altyd 'n belangrike rol gespeel in die formulering van die meeste variante van die Marxistiese ideologie.

Wanneer die teologie antwoord moet gee aan sentrale vrae rondom die verhouding koninkryk en tydelike lewe, of die sentrale rcligieuse liefdesgebod se betekenis vir die konkrete sosiale verhoudinge, dan ,schijnen we uitgeleverd te zijn aan de primitieve idealen van het Neo-Marxistisch utopisme inzake radikale democratisering, medeverantwoordelijkheid, ongenuanceerd medebeslissingsrecht, collectivisering van produktiemiddelen, egalisatie van macht, van inkomens, van bezit, ontluistering van gezag enz". (Troost, A. p.5). Dit alles word nou teologies begelei. Die Christene dek dit met woorde wat aan die Bybel ontleen is asof die "links gerigte" strominge (Marxisme) eintlik dieselfde ideale as die Christendom nastreef. Ook Z. Roter (aangehaal deur Mojzes, p. in J.E.S. 9, 1972, p. 18) is van mening dat "Christianity and marxism have the same tradition, the same problem, that they each have emphasis which could enrich the other, that they share a world which is in danger of manifold self-destruction unless the two cooperate for the sake of mankind" (kursivering van my).

Die verklaring van die sintese hang ten nouste saam met die Marxiste se steeds ontwikkelende beskouinge oor die wese en verskynsel van die religie. (Vir voorbeelde, vgl. Mojzes, p. 12 e.v.)

As daar dan sprake is van 'n tweerigting-verkeer (van beide kante af toenadering - vgl. die teologie van die dialoog), dan is die sintese wat so gevorm is 'n konglomeraat van onsuiwer marxisme plus onsuiwer religie met 'n (totaal?) nuwe inhoud en doelstelling naamlik die humanisering van die mens - 'n nuwe toring van Babel: die utopistiese A-mens samelewing gebou op model van die eskatologie (n.a.v. die Bybelse-) met behulp van metodes en strategie eie aan die revolusiedenke (na analogie van Marx). 
A. Kee (1972, p. 22), uit ander oorwegings, rig hier 'n ter sake waarskuwing: "A first reaction among Christians might be selfcongratulation: the neo-marxists have at last begun to follow our path. But a moment's reflection on the actual character of the churches or the historical relationship of the West to the underdeveloped world, show that this smug paternalism is quite out of place" (kursivering van my).

4. Nog 'n probleem is die verhouding tussen die filosofiese en die „teologiese neomarxisme". Ek wil dit betwyfel of ons die twee strominge hoegenaamd op een lyn kan plaas. Die teologiese neomarxisme (met name dié van Bloch, Shaull, Verkuyl) het wel van Marcuse kennis geneem, maar nie eintlik iets van hom oorgeneem nie. Miskien moet ons dit so sien dat beide lyne parallel langs mekaar as Neo-Marxisme uit Marx uit ontwikkel het. Die filosofiese Neo-Marxisme is daarin nuut dat hulle Freud, Sartre en andere opgeneem het. Die Teologiese Neo-Marxisme het weer die Bybel in hul Marxistiese lendene opgeneem. Of andersom gesê: die nuwere teologie het by die oop-Marxisme aansluiting gevind.

Dit sou dus fout wees om die teologiese Neo-Marxisme (bv. soos dit gestalte kry via die W.R.K.) sonder meer te gaan gelyk stel met die New Left - en tog is daar korrelatiewe ooreenkomste

\section{Teologiese Neo-Marxisme}

Die vraag: „Wat is Neo-Marxisme?" moet vir doeleindes van hierdie studie uitgaan van die simptomatiese en feitelike sintese wat daar reeds bestaan tussen die teologie en die Marxisme. Hierdie sintese bestempel ons as "Teologiese Neo-Marxisme" wanneer ,Teologiese Neo-Marxisme" dieselfde grondtrekke vertoon as die filosofiese (Vgl. paragraaf 4.4). Binne die Teologiese Neo-Marxisme is daar verskeie variante aantoonbaar. Dikwels vloei hulle inmekaar en ewe dikwels staan hulle diamentraal teenoor mekaar. Binne elke variant kom ook gradasies voor.

\subsection{Die Teologie van Hoop}

' $n$ Eerste variant van die Teologiese Neo-Marxisme is Ernst Bloch (opgevolg deur J. Moltmann e.a.) se filosofiese Teologie van Hoop. Bloch word allerweë beskou as bekende Neo-Marxis (Vgl. Floor, L. 1976 , p. 19). Hy is Marcuse se „teologiese” boetie; beide stam uit die Frankfurter Schule.

Bloch beoog konsekwente vernuwing van die ou Marxisme wat volgens hom te dogmaties, teoreties en materialisties geword het en te min oog het vir die kulturele wetenskappe en die religie. (Vgl. Van Dijk, M. P., 1974, p. 17, 18 en Heyns, J. A. 1975, p. 24-38). Hoewel hy 'n selferkende ateis is, wil hy die waarheid van die geontmitologiseerde godsdiens behou: die hoop, die droom, die utopie van die homo absconditus (mens wat nog nie is wat hy moet wees nie). Hy handhaaf, (soos alle humaniste, Marx, Marcuse e.a.) 'n onbeperkte optimisme m.b.t. die antropologie: Mens is 'n son wat om homself draai (Marcuse). Hierdie manjifieke wese kan en sal 'n klaslose, ellende-lose samelewing skep waarin almal opgeneem sal word in die heerlike kollektivisme. 
Bloch maak uitvoerig van die Bybel gebruik om aan sy idees lewensvatbaarheid te verleen. Die Ou Testament is die boek van God se bevrydingsbeweging. Jesus se prediking sentreer om die exodus-motief van bevryding/verlossing uit die gevangenis van die gevestigde orde waarin uitbuiting, ongeregtigheid en onderdrukking die toon aangee. Hierdie exodus-God bly egter 'n nie-noodsaaklike werkshipotese agter die proses van bevryding. Daarom, sê hy, kan alleen 'n ware ateîs 'n goeie Christen wees en omgekeerd.

Hicrmee is die Bybel-hermeneutiek van die Teologiese NeoMarxiste in beginsel neergelé (weliswaar nie vir die eerste keer deur Bloch nie!)

Bloch is m.i. 'n Neo-Marxis omdat hy met Oop-Marxisme die Bybel inlaat en die Jeremiaanse tema (humanisme van die sg. ,jonge Marx") oorneem en besonder op die hoop klem lê, die maakbaarheid van die toekoms. Dit gee aan sy teorie 'n futurologiese karakter.

\subsection{Die Teologie van Revolusie}

Die Teologie van die Revolusie het in Suid-Amerika ontstaan as reaksie op die uitdagings van die kommunistiese bedrywighede in Latyns-Amerika. Dit het egter in lyn daarmee of na analogie daarvan, sy gestalte verkry. Rendtorff, F. en Tödt, H. E. 1968, p. 51, ook p. 214-6). Die "Sitz im Leben" vra ons simpatie sodat ons nie sondermeer as „kommunisme" kategoriseer nie, maar dit maak hulle ook nie sondermeer "Christene” nie.

Die revolusionêre bewusmakingsproses tot 'n nuwe sosiaal-etiese strategie geskied transedent van buite af d.m.v. (1) losmaking van konfessionele bindinge; (2) kontak met selfs nie-Christelike groepe wat saam sock na die nuwe mensheid; (3) samewerking (koinonia) met die oorkoepelende universele „christelike" gemeenskap in 'n permanente revolusie (a.w. p. 55-6). Gevolglik is Christene daarvan onthef om standpunt of vir of teen die nie-christelike Marxistiese revolusie in te neem. Terselfdertyd word alle poginge tot „sosiale vernuwing" sonder meer as "Christelike sending" en deelname daaraan as partisipasie aan "Gods humaniserende handele in die geschiedenis" geïnterpreteer" (a.w., p. 60, 63). Die gedagtes is van M. Buber en P. Lehman afkomstig (p. 26, 27, 36).

Die Teologie van die Revolusie distansieer homself van die gedagte van ,individuele vroomheid" en rig sig op die "sosiale omvorming". In die woorde van E. Castro (aangehaal op p. 60, 74. Ek onderstreep): Wij zijn in stat de werkelijkheid van onze bekering te meten aan de mate waarin wij ons inzetten voor de strijd om sociale gerechtigheid en ons los maken uit de bestaande sociale systemen."

Beskouings van R. Shaull en J. Verkuyl as illustrasie

Richard Shaull beskou die Christendom as daardie ,eksplosive kracht" wat hom in staat stel om die revolusie oor die knop te stoot; om die onmoontlike aan te pak in die vaste vertroue dat die konink. ryk van God kom. (Rendtorff, F. en Tödt, H. E. a.w., p. 23). Die kerk kan nou weer 'n revolusionére $\mathrm{krag}$ word (p. 181). Kerklike revolusie hou vir Shaull in: Die Bybel leer slegs 'n revolusionêre God wat 
die mag van die onderdrukker verbreek en verneder, maar verslanes oprig (Rendtorff en Tödt, a.w. p. 182, vergelyk H. Berkhof in dié verband); strukture moet eskatologies-gerig voortbeweeg na nuwe strukture; Jesus is die vleesgeworde politieke revolusionêr wat 'n swaar aksent plaas op „het messiaanse thema van verwoesting en vernieuwing" (a.w. p. 182); God maak met Christus se koms en die werk van die Heilige Gees nuwe verontruste kragte los in „de strijd om de humanisering" t.o.v. „een rechtvaardige menselijke ordening" (a.w. p. 184); die christen moet „zeer geëngegeerd" aan die stryd om „humanisering" deelneem en gedurig met Bybelse en teologiese erfgoed oor die revolusie in gesprek wees; versoening is horisontaal: „Verzoening van tegenstrijdige belangen en herstel van verbroken betrekkingen" en bied die moontlikheid tot medeseggenskap in die lot van die toekoms (a.w. p. 185, 198). Dit realiseer vir Shaull die Christelike Koinonia. Wiersinga sluit by Shaull aan (Floor, L., 1972 p. 24).

J. Verkuyl (heethoof van die Teologiese Neo-Marxisme) verwys in sy „Verantwoorde revolusie" $(1970$, p. 14) na Lehmann en Buber se idoom "Jhwe de Slavenbevrijder" en wil liewer praat van 'n „theologie der transformatie" as van „-revolutie” (p. 11). Hy noem enkele "dogmatische themata, die om nadere uitwerking vragen" (p. 53-58): Kollektiewe, institusionele en strukturele sondes wat deur God gestraf word; versoening veral tussen mense in die samelewing, die gesin, huwelik, in rasseverhoudinge ens.; bekering van volke en samelewingsgroepe in hul institusionele en strukturele organisasie; die handele van God in die geskiedenis ,overal waar de liefde tot God en de naaste tot opbloei komt ,moet erken word want' het kan zijn dat de kerken in een bepaalde phase der geschiedenis broeistenen van haat en onderlinge twist geworden zijn" (p. 56, 57); die vervulling van die tye: „Nu is het tijd ... om de vragen van de sociale relaties, de vraag van de verhouding tussen rijke en arme landen en de vragen van oorlog en vrede aan te grijpen" (p. 58); eskatologie wat uitloop op die nuwe aarde (waarin die mens alles sal wees en in almal M.C.B.) nie net vir individue nie, maar veral vir die ganse aarde, stad en kosmos.

Wanneer Verkuyl die samelewing wil aktiveer tot ,transformatie" stel hy die volgende strategie (p. 60 e.v.) voor: Politieke, sosiale en ekonomiese opvoeding; dinamisering van „parlementêre demokrasie"; opposisie deur woord en geskrif; petisie en demonstrasie (op patroon van Gandhi, Luthuli en Martin Luther King se ,geweldlose verset); stakings maak dit moontlik ,het gezagsapparaat geheel te verlammen en daarmee de weg tot gezagsovername voor te bereiden" (p. 80); revolusie as "laaste" (maar beslis tog wel!) uitweg.

Die aandeel van die Christen in en na die revolusie word ook aangedui. Ons verwag, sê Verkuyl, 'n nuwe hemel en 'n nuwe aarde, „een ,home' van gerechtigheid" (p. 93). Die nuwe aarde is sonder ongeregtigheid tussen rasse - en die Christen is geroep om mee te stry met dié wat nou honger en dors na rasse-geregtigheid (p. 91, 92). Die nuwe aarde is sonder ekonomiese ongeregtigheid - gelyke ver- 
deling van besit; op die nuwe aarde sal sosiale geregtigheid woon; daar sal kulturele geregtigheid wees; daar sal ten slotte politieke geregtigheid heers.

Deurgaans praat Verkuyl van politieke, ekonomiese en sosiale strukture wat manifestasies is van "geïnstitutionaliseerde rassisme oftewel strukturele sonde”. Dit moet afgebreek word. „Er kan geen gerechtigheid in onze wereld komen zonder een transfer van economische bronnen om de herdistributie van politieke macht te ondersteunen en om de culturele zelfbeschikking zinvol te maken" (p. 78. Ek onderstreep!)

\section{Samevattend}

Die Teologie van Revolusie is die duidelikste eksponent van die Teologiese Neo-Marxisme as Neo-Marxisme. Die kerk en sy gelowiges plus die wêreld en sy ateīste, vorm die nuwe proletariaat of dan in elk geval die revolusie-agente namens die verdruktes en noodlydendes (wat in elk geval selektief aangedui word). Jesus en God word die prototipes van die politieke en maatskaplike revolusie waaraan die gelowiges moet deelneem sou die kerk ooit nog op voortbestaan hoop as 'n „dade-christendom" (vgl. Helberg, A. N. 1976 , p. 45,46 , verwys na Elsevier 16.10 .71 , C. W. Monnich). M.b.t. die futurologie kan die Teologiese Neo-Marxisme verleidend verkondig dat die heilstaat gou en met groot sukses op pad is. „Die Marxistiese heilstaat word vereenselwig met die koninkryk van God" (Van Wyk de Vries, K. S. 1967, p. 33). Vir die eerste keer in die wêreldgeskiedenis (Gnosis, Rassionalistiese vooruitgangsgeloof en Marx ten spyt) word 'n oplossing vir ondermaanse ellende op „copy" van Bybelse eskatologie aangebied. „Wij zoeken vandaag naar een nieuw leven dat nog nergens plaats vind, een utopie" (Wiersinga, H., 1972, p. 13. My kursivering. Vgl. Verkuyl, J, 1970, p.58 e.v.).

Beide Shaull en Verkuyl kritiseer die status quo-kerk wat so sterk ou die individuele saligheid konsentreer dat die impak van die Evangelie op politiek en kultuur nie tot sy reg kom nie. Verkuyl skryf nadruk op individuele saligheid aan piëtistiese non-aktuele Skrifinterpretasie toe asof piëtiste en maghebbers stilweg afgepraat het: ons konsentreer op die siel se hiernamaals en die politici en ekonome sorg vir die handhawing van die status quo. Verkuyl (en Shaull) is gekant teen die Gereformeerde leer van persoonlike verlossing (in Christus) en wyk van Marcuse se ekstreme individualisme af om konsekwent aan 'n sosiale soteriologie te bou, 'n kollektiewe futuristiese, universele, humanistiese en kosmiese selfverlossingsleer deur die daad. Ten slotte moet ons daarop wys dat ons nog maar net die Teologie van revolusie aangeraak het.

\subsection{Die Teologie van Dialoog}

Die Teologie van die dialoog is die besondere wyse waarop al die vorige variante vanuit Oos-Europa gestalte gekry het. Die geskiedenis van dialoog tussen Marxiste en Christene moet nog grootliks geskryf word. Aan die Oos-Europa dialoog het o.m. A. Schaff, H. 
Kolakowski, Gardavsky (sy boek „Gott ist nicht ganz tot” 1970), die Fransman R. Garaudy en andere vorm gegee.

Kolakovski (van Tsjeggoslowakye) handhaaf Marxisme met dien verstande dat daar ruimte gelaat word vir (self) kritiek en hersiening. Sy „Neo-Marxisme" wil dus geen geslote sisteem wees nie, maar 'n metode van leef en dink wat verskeidenheid soek. Die godsdiens meen hy (volgens Sperma Weiland, 1971, p. 48 e.v.) het te doen met „egte raaisels". Die Neo-Marxisme is 'n nuwe formulering van hierdie "egte raaisels". Die mistieke van die eskatologie, die theodicee, die verkondiging natuur-genade m.b.t. „god" en sy verhouding tot die mens moet egter verval. Kolakowaski reduseer Jesus tot 'n Joodse profeet wat vergoddelik is en die eerste kommunis was.

\section{Joegoe-Slavië en Tito}

In Joegoe-Slavië begin die gesprek Christen-Marxis al voor Wêreldoorlog II. Eers het die Christene (oorwegend Rooms Katolieke) die Marxiste vervolg. In Wêreldoorlog II moes Tito se kommunistiese vryheidsvegters die land verdedig teen Nazi-oorheersing. 1944 kry Tito se magte die oorhand en Joegoe-Slavië word die eerste Oos-Europese land geregeer deur 'n kommunistiese party (o.l.v. Tito). Toe is kerke weer verwoes en Christene vervolg. 1948 breek Tito weg van die Russiese model van kommunisme. Hy wou 'n nuwe sosialisme daarstel waarin meer individuele vryheid aan mense gegee word. 1953 - 1962 word gekenmerk deur al-hoe-meer verdraagheid en die ontwikkeling van die idee van selfbestuur. Die amptelike kerkvervolging is gestaak.

1962 - 67 het Tito se regering "much of the overtly propagandistic anti-religion jargon" laat vaar. (Mojzes, P., 1972, p. 10). „The greatest single catalyst for change was the activity of Pope John XXIII and the second Vatican Council" (p. 10). Daar is selfs 'n religieuse perswese toegelaat en Marxiste het begin om die godsdiens-verskynsel te evalueer. Uiteindelik is dit opgevolg deur 'n vloedgolf van dialoog, boekbesprekings, kritiek, dosente-ruil, T.V. gesprekke e.d.m. 'n Nuwe geslag Marxiste kom te voorskyn wat hulself „Neo-Marxiste” noem!

Ook hier kom die deurlopende „Jeremiaanse tema" van alle na-Marxvariante asook die basies horisontalisme en humanisme voor. 'n Sekere Cimic skryf byvoorbeeld dat ons die dialoog moet beskou as ",necessity for Christians and a sensible approach for Marxists in their effort to build socialism". Verder: „A religion may be a mode of humanization and may serve a progressive role.... Out of such a religion will perhaps emerge a more acceptable humane atheism." (Cimic - een van die Marxiste, aangehaal deur Mojzes, P., 1972, p. 16, 17. My kursivering). „Revolusie” word geraffineer tot „dialoog" - 'n vorm van self-revolusie. „Life transcends the contradiction of materialist - idealist and atheist. Marxists and Christians both need to work on humanizing men, something that is in the tradition of both movements." (Fiamengo, 'n Marxis aangehaal deur Mojzes, P., 1972, 6. 16). Die futurologie is wel ook omlyn maar nie so helder soos by Verkuyl en Wiersinga nie. 


\subsection{Die Swart Teologie}

Die Swart-teologie wil 'n hervormingsbeweging wees. Boesak wil swart en wit weer in vrede (horisontaal) versoen nadat die „pseudoonskuld" (met ander woorde werklike skuld) uit die weg geruim is. Dit is 'n religie wat gemik is op vryheid en menslike welvaart; om geregtigheid en vryheid vir die swartman te verkry. Die idee is nie om berou op te wek nie maar wel: "farewell to innocence" (titel van Boesak se boek!).

Swart-mag-teologie bly vir my in die prentjie van Neo-Marxisme. Dit is m.i. die jongste manifestasie van die piramidale histories opgeboude Neo-Marxisme. Die Swart-mag-teologie is die swart weergawe van die Neo-Marxisme (prof. C. W. H. Boshoff in persoonlike gesprek. „Swart Teologie is dan die teologie van die revolusie teen die Witman; die teologie van die bevryding van die kolonialisme; die teologie wat 'n sosio-politieke verandering in Suid-Afrika eis. Uiteindelik 'n teologie van Swart heerskappy" (Woord en Daad, Augustus 1972, p. 6).

\subsection{Waar die hekseketel geroer word: Die Wêreldraad van Kerke}

Die WRK is die konsentrasiepunt van alle variante van die Teologiese Neo-Marxisme en genoemde genitief-teologië (waarvan daar nog meer is met nog meer interverwantskappe).

Die aandeel van die WRK om die sintese tussen Marxisme en Teologie daar te stel is bykans onbepaalbaar. Die WRK bemoei hom by uitstek met die ,ongeregtigheid" van die VSA se Viëtnam politiek en die ,wrede rassistiese regime van die RSA en SuidRhodesië" (Bundy, E. A., 1967, p. 145). Volgens Verkuyl (1972, p. 56) is die beleid van die WRK van die begin af (1954) om „een broederschap te vormen waarin voor segregatie of discriminatie geen plek is."

In Desember 1961 te Nieu-Delphi word die Russiese Ortodokse Kerk as lid van die Wèreldraad van Kerke toegelaat. Hierdeur is aan die Russiese regering se propaganda-arm onder 'n godsdienstige fasade nog ' $n$ platform gebied waarvandaan die Vrye Wêreld aangeval kon word. Die skokkendste voorbeeld van sodanige aanvalle word treffend geillustreer deur die derde Algemene Vergadering van die Wêreldraad van Kerke in 1966 te Geneve. Hier stel M. Nikodim (Buitelandse Sekretaris van die Russiese Ortodokse Kerk en K.G.B. agent!), dat „Christene” in die Sowjet-unie die sosialistiese revolusie aanvaar het, en ook aktiewe bouers is aan ' $n$ klaslose maatskappy, 'n sosialistiese gemeenskap wat vry is van enige eksploitasie, rasse- of enige ander ongelykheid (Bundy, E. A., 1967, p. 152). Op dieselfde Geneve-byeenkoms lewer Opperpriester Borovoy 'n referaat oor die uitdaging en openbaring van die Teologie tot die sosiale revolusie van ons tyd. Hierin maak Borovoy onverbloemd propaganda vir die Marxistiese revolusie en koppel die Marxistiese credo aan die leerstellinge van Christus. Hy haal byvoorbeeld aan uit die Bybel, die grondwet van die Sowjet, Marx en Engels (p. 155). Dit was ook op hierdie 1966 Geneve-vergadering dat die Teologie van die Revolusie sy debuut gemaak het by monde van $R$. Schaull ( $p$. 166). Hierdie „ongelooflike gelykstelling van die kommunisme met 
die Christendom" is vir Bundy 'n „,supersoniese skok" (p. 158-9). Die vierde Algemene Vergadering van die WRK te Uppsala 1968 se belangrikste tema was die vraagstuk van rasseverhoudinge (Verkuyl, J. 1969, p. 71, 76, 77; 1972, p. 8, 9, 12, 13). Uppsala word in Mei 1969 opgevolg deur die ,schokkende” (Verkuyl) Notting Hill om met verteenwoordigers van die versetbewegings samesprekings te voer. Hier het dit duidelik geword dat die kerke nie meer kan volstaan met verklarings nie, "maar dat ze de roeping hebben processen van verandering op gang te brengen door een mengsel van informatie, studie, verklaringen, aktie en experimenten" (Verkuyl, J., 1969, p. 78. My kursivering).

Augustus 1969 vind daar 'n opvolgbyeenkoms plaas te Canterbury waar die tema van ",herstelbetaal" aan die orde gestel word (Verkuyl, 1969, p. 78), die P.C.R. in werking gestel en etlike duisende dollers bewillig word vir 'n fonds ter ondersteuning van die versetbewegings ${ }^{68}$. „,De Wereldraad onderstreept hiermee haar onvoorwaardelijke solidariteit met de raciale groepen die streven naar vrijheid en verantwoordelijkheid binnen de wereldsamenleving" (Verkuyl, J., 1972, p. 68).

Met die skrywe van sy boek „Bestrijding van het racisme" in 1972 suggereer Verkuyl al die derde fase van die anti-rassisme stryd. Hier gaan dit veral om die kwaliteit van die solidariteit en is gebaseer op 'n etiek van geweld as kontrageweld teen strukturele en onderdrukkende geweld (p. 27-33). Daarvoor is verskillende donasies aan die ANC gemaak. Ten opsigte van die gebruik van geweld stel Verkuyl dat die Wêreldraad van Kerke nie daaroor 'n oordeel uitspreek nie maar stel hulself aan die kant van die onderdrukkers en laat die besluit aan die slagoffers oor! T.o.v. SA beoog Verkuyl 'n struktuur ,waarin het machtsmonopolie der blanken vervangen wordt door een gouvernementele structuur, waarin alle bevolkingsgroepen deelnemen aan het centrale verantwoordelijkheid en politieke rechten en verantwoordelijkheden verwerven" (p. 32).

\section{SLOTSAMEVATTING}

Daar is ten minste vier lyne onderskeibaar in die na-Marxse ontwikkelings. Al vier word deur verskillende verklaarders om een of ander rede bestempel as „Neo-Marxisme”. Weinig van Marx se oorspronklike teorieë word net so teruggevind in enige van die vier strominge.

Ons wil die na-Marxe ontwikkelingslyne met die volgende name aandui: Kommunistiese Marxisme, Ortodokse Marxisme, Filosofiese Neo-Marxisme en Teologiese Neo-Marxisme.

1. Die Kommunistiese Maxisme soos verstalt in die U.S.S.R. en Sjina. Stalin was hier die hooffiguur. (Ook genoem NasionaalSosialisme).

2. Die Ortodokse Marxisme wat beskou kan word as die suiwerste Marxisme op die moderne tye toegepas. Hooffiguur is I. Deutscher. (Ook genoem Trostkyïsme of Internasionaal-Sosialisme). Die twee strominge is beide as „Marxisme" noembaar en dra die volgende kenmerke: 
(i) Hul geslote houding: Marx te teorie word gewysig maar behou sy gesig. Die aanpassings kom vanuit eie (kommunisties/Marxistiese) geledere.

(ii) Hul aansluiting by die sentrale tema van alle Marxistiese variante t.w. die geloof/hoop in die menslik-maakbare toekoms waarin alle ellende opgeruim is. Takties geskied dit deur die afbrak van die status quo en die selfopbou van die utopie.

(iii) Hul vae futorologie. Hulle aandag word primêr bepaal deur die tegniek van die afbraak (negatief gestel) - met slegs enkele pennestrepe t.o.v. die toekomsverwagting. Dit korreleer met Karl Marx se vaagheid betreffende die verwagte utopie in teenstelling met sy detaileksegese in Das Kapital van die revolusionêre stadium en nét daarna.

3. Die derde hooflyn in die na-Marxse ontwikkeling word omskryf deur die term ,filosofiese Neo-Marxisme". Hiervan is die Frankfurter Schule (Horkheimer, Adorno, breër uitgewerk deur Marcuse en Habermas) die bakermat. Marcuse kan as hooffiguur beskou word.

Hierdie rigting verskil korrelatief van die Marxisme in die volgende opsigte (en omlyn hiermee die begrip Neo-Marxisme):

(i) Hulle handhaaf die genoemde "sentrale tema" onverswak hoewel die toepassing daarvan verskil. Die hoop op die nuwe toekoms kry nuwe lewe sodat (ii) hul futorologie helderder omlyn kan word. Weliswaar wil hulle geen nuwe „establishment" skep nie en daarom moet die revolusie permanent voortgaan. Die nuwe mensheid sal egter optimaal humanisties daar uitsien. Hiermee wil hulle Marx se vaagheid invul op 'n neohumanistiese, neo-liberalistiese wyse.

(iii) Konsekwent handhaaf hulle 'n oop interpretasie van Marx: Marcuse werk Freud by .... (P. Thoenes bring die sosiologie by. Shaull bring die teologie by ....) Hierdie openheid, waardeur ruimte gevind word vir die akkommodasie van nuwe idee-wêrelde binne die sentrale tema van die Marxisme, is die een faktor wat die belangrikste bydrae lewer tot die identiteit van die Neo-Marxisme.

(iv) Konsekwent vind die Neo-Marxisme aansluiting by die humanisme van Karl Marx en dan wel soos dit tot openbaring kom in die geskrifte uit sy jong dae. Daarom kan die Neo-Marxisme bestempel word as neo-humanisties en horisontalisme.

4. Die vierde hoofstroming, die "Teologiese Neo-Marxisme" besit dieselfde identiteitstrekke as die filosofiese Neo-Marxisme.

(i) Die oop-heid akkommodeer die Teologie (God en die Bybel): 'n handomkeer van die wêreld binne 15 jaar. 'n openlike aggressiewe antitese tot selfs „vredesoekende" dialoog tussen Marxiste en Christene. 
(ii) Die Neo-humanistiese horisontalisme (vgl. die sg. ,jonge Marx") spreek uit hul optimistiese antropologie (mens kan en moet homself verlos deur die daad) en hul volgehoue en wyd-verkondigde sosiale soteriologie (ongeregtigheid tussen mense moet verdwyn).

(iii) Hulle sluit aan by die "sentrale tema". Takties word kerk, gelowige, anti-teis en samelewing opgeroep om saam te werk aan wat as "Gods humaniserende handele in die geskiedenis" geïdentifiseer word.

(iv) Die geloof (die revolusionêre prinsipe - sê Wiersinga) en die hoop op die utopie kry helder gestalte. Die utopie word nou daadwerklik reikhalsend gekoop met elke sent kollekte „geld vir geweld". Hulle solidariteit in en d.m.v. liturgie met die vryheidsvegters voer die botoon.

Die Teologiese Neo-Marxisme (sintese tussen Marxisme en Teologie) is die enigste wat werklik aan die naam van Karl Marx die eeu-oorspannende lewenskrag verleen het. Dit ontleen nie veel aan sy filosofiese eweknie nie, maar het selfstandig langs die filosofiese Neo-Marxisme vanuit Marx en Teologie gegroei. Beide is kinders van Karl Marx, een het met Freud en die ander met die Bybel getrou.

Al die sogenaamde „kritiese teoloë” is sekerlik nie sonder meer Neo-Marxiste nie. Alle Neo-Marxistiese teoloë is ook nie sonder meer kommuniste. Ons moet d.m.v. Apologetiek wetenskaplik-analities gaan onderskei tussen wie is broeder in die geloof in Christus die Seun van God (gereformeerd gekwalifiseerd) en wie is profeet van die Antichris.

\section{BIBLIOGRAFIE}

BUNDY, E. C. 1967. Die Wêreldraad van Kerke. In Oorlog om die volksiel. Referate gelewer by die Internasionale Simposium oor Kommunisme. Sept. 1966 Potch. Herald, Potchefstroom, 1967.

DEUTSCHER, I. 1972. Marxism in our time. London, Cape. Artikels: „On socialist man"; „Trotsky in our time".

DUVENAGE, S. C. W. 1972. Gesagsverhoudinge - prinsipieel belig en toegepas op die akademie. I.B.C. studiestuk No. 61, P.U. vir C.H.O., 1972.

DUVENAGE, S. C. W. 1973. Studenteopstandigheid as middel van politieke geweld en revolusie. In Politieke geweld en revolusie. 'n Simposium aangebied deur die Sentrum vir Internasionale Politiek. 24 Aug. 1973. P.U. vir C.H.O., Pro-Rege. Potchefstroom.

FLOOR, L. 1976. Die Neo-Marxisme in die moderne teologie en ons antwoord daarop. In In die Skriflig. 10 (39) 1976, p. 17.28.

HELBERG, A. N. 1976. 'n Inleiding tot die bespreking van Neo-Marxisme in die kerklike lewe en ons antwoord daarop. In In die Skriflig 10 (39) 1976, p. $45 \cdot 47$.

HEYNS, J. A., 1969. Sterwende Christendom - 'n Teologie in die greep van die tydgees. Tafelberg. Kaapstad.

HEYNS, J. A. 1975. Teologie van revolusie. Tafelberg, Kaapstad.

KEE, A. 1972. Learning from other faiths. VIII Neo-Marxism. In J. 1 the Expository fimes. 84(1) 1972, p. 19 - 23. 
KOTZE, D. J. 1977. Kommunisme vandag. Tafelberg, Kaapstad.

KRAAN, K. J. 1957. Het Marxisme na Marx. In Denkers van deze eeuw. II Wever, Franeker.

MOJZES, P. 1972. Christian-Marxist encounter in the context of a socialistic society. In Journal of Eccumenical Studies (J.E.S.), 9, 1972, p. 1 - 28.

NOLAN, A. Marx and the Marxists. Missionalia, 6(1) 1978, p. $3-15$.

RENDTOIRFF, F., en TöDT, H. E. 1968. Theologie der revolutie.

ROTER, Z. 1972. A Marxist view of Christianity-the meaning of the dialogue between Christians and Marxists. In J.E.S. 9, 172, p. 50-50.

THOENES, P. 1964. De verloochening van het Marxisme. Gorcum, Assen, 1964. TROOST, A. 1969. Het Neo-Marxisme en de „theologie der zamenleving”. In Mededelingen van de vereeniging voor Calvinistische wijsbegeerte. 1969(a) p. 356 (Maart) en 1969(b) p. 3 - 6 (Junie). ( 2 opvolgartikels).

VAN DIJK, M. P. 1975 De uitdaging van het Neo-Marxisme. Buiten en C. Schippenheijn, Amsterdam.

VAN WYK DE VRIES, K. S. 1976. Neo-Marxisme en die kerklike lewe. In In die Skriflig 10(39) 1976, p. 32 - 44.

VERKUYL, J. 1969. Breek de muren af! - Om gerechtigheid in de rassenverhoudingen. Oekumene. 1969.

VERKUYL, J. 1970. Verantwoorde revolutie - over middelen en doeleinden in de strijd om transformatie van de samenleving. Door J. Verkuyl en $\mathbf{H}$. G. Schutte.Noordhold. Kok, Kampen. 2e druk, 1970.

VERKUYL, J. 1972. Bestrijding van het racisme en de kerken in Nederland. Het programma van de Wereldraad van Kerken. Kod, Kampen.

WEILAND, S. J. 1971. Voortgezette oriêntatie - nuwe wegen in de theologie. Het Wereldvenster, Baarn. 2e druk (uitgebreid) 1971.

WIERSINGA, H. 1972. Verzoening als Verandering - een gegeven voor menselijk handelen. Oekumene reeks. 2e druk 1972.

ZUIDEM $\Lambda$, S. U. 1970. Revolutionaire Maatschappijkritiek van Herbert Marcuse. Buiten en Schipperheijn, Amsterdam. 